\title{
The Effect of Growth Conditions on Respiratory Activity and Growth Efficiency in Facultative Anaerobes Grown in Chemostat Culture
}

\author{
By D. E. F. HARRISON* AND J. E. LOVELESS \\ Water Pollution Research Laboratory, Stevenage, Hertfordshire
}

(Accepted for publication 22 June 197I)

SUMMARY

The effects of temperature, $\mathrm{pH}$, dilution rate and oxygen tension on the yield coefficient and respiration rate of Klebsiella aerogenes and Escherichia coli grown in continuous culture were studied. Reduced cell yields and increased oxygen uptake rates were obtained at low oxygen tension $(2$ to $5 \mathrm{mmHg}$ ) without any increase in the concentration of extracellular organic carbon. These effects and changes in the respiration rate with changes in the dilution rate are discussed in relation to the 'energy efficiency' of the cells.

\section{INTRODUCTION}

In the majority of microbial processes in industry the aim is to convert a maximum amount of substrate to cells or useful product. For waste treatment, however, it is desirable to oxidize substrate to carbon dioxide as fast as possible with minimum production of cell mass. At present most sewage and industrial wastes are treated in completely aerobic systems chiefly because this is thought necessary to maintain the physical characteristics of a fast settling sludge. Assuming that other methods for removing solids from suspensions will be found, it is important to know what conditions would be expected to produce least cells for maximum oxidation rates.

Klebsiella aerogenes respired faster at low oxygen tensions below a 'critical value' than under fully aerobic conditions and in this state the cell yield was decreased (Harrison \& Pirt, 1967).

The 'potential' respiration rate (i.e. respiration rate of a sample when exposed to excess oxygen and excess substrate) of cells grown in continuous culture was higher in anaerobically grown cultures than in fully aerobic cultures (Harrison, Maclennan \& Pirt, I969). In the present work an attempt is made to determine the way in which the physiology of the cell changes to adapt to different growth conditions.

\section{METHODS}

The organisms used in this work were Escherichia coli I (NCIB 86) and Klebsiella aerogenes 8017 (NCIB).

Culture technique. The bacteria were grown in a $\mathrm{I} \cdot 51$. Porton-type chemostat vessel (Elsworth, Meakin, Pirt \& Capell, 1956) equipped with automatic control and recording of $\mathrm{pH}$ and temperature. The dissolved oxygen tension in the culture was recorded using either a Mackereth probe (Mackereth, 1964) or a steam sterilizable version of this probe

\footnotetext{
* Present address: Shell Research Ltd, Borden Microbiology Laboratory, Sittingbourne, Kent.
} 
(Harrison \& Melbourne, 1970). A synthetic medium was used containing glucose $\left(5^{\circ} \mathrm{og} . / \mathrm{l}\right.$.) as the sole, limiting carbon source (Harrison \& Pirt, 1967). The oxygen tension in the culture was regulated via the proportions of air and nitrogen in the feed gas. Anaerobic conditions were obtained by feeding 'white spot' nitrogen gas (BOC, Wembley, Middlesex). No steps were taken to eliminate the small amount of oxygen dissolved in the medium in the reservoir or to prevent diffusion through silicone bungs, etc.

Analytical techniques. Dry weights were determined on $30 \mathrm{ml}$. centrifuged, washed samples. Glucose was determined by the hexokinase method (Slein, 1965) and by the anthrone method (Trevelyan \& Harrison, 1952). Cell and supernatant carbon determinations were made using an infrared carbon analyser (Beckman Instruments), and cell nitrogen was determined by the Kjeldahl technique (Magee, 1955); these determinations were carried out by the Analytical Section of the Laboratory.

Carbon dioxide production was monitored by passing the effluent gas from the culture through a 'Lira 300' infrared $\mathrm{CO}_{2}$ analyser (Mine Safety Appliances Co. Ltd, Glasgow). The oxygen in the gas phase was measured using a Mackereth oxygen probe (Briggs, Melbourne \& Eden, 1966). The gas was moistened and temperature equilibrated before passing through the probe assembly.

Measurement of $Q_{\mathrm{O}_{2}}$. The 'potential' respiration rate of cells grown under glucose-limited conditions was measured by diluting samples from the culture in air-saturated buffer, adding excess glucose (Io mg./ml.) and following the oxygen uptake in an oxygen electrode respirometer (Rank Bros., Bottisham, Cambridgeshire).

The 'potential' $Q_{\mathrm{o}_{2}}$ was calculated from

$$
Q_{0_{2}}(\text { mmole } / \text { g. h. })=\frac{r}{x d}
$$

where $r=$ rate of depletion of oxygen concentration as measured in the oxygen electrode cell (mmole/1. h.), $d=$ dilution factor, $x=$ concentration of organism (g. $/ 1$.).

The 'in situ' $Q_{\mathrm{o}_{2}}$ of the culture, used for the respiration rate of cells as they grow in the culture vessel, was calculated from

$$
\left.Q_{\mathrm{o}_{2}} \text { (mmole/g. h. }\right)=\left(C_{1}-C_{2}\right) \frac{P}{760} \frac{273}{T+273} \frac{f}{\mathrm{IO0}} \frac{60}{22 \cdot 4} \frac{\mathrm{I}}{x V}
$$

where $C_{1}=$ oxygen in gas supply $(\%), C_{2}=$ oxygen in effluent gas $(\%)$ corrected for volume change if necessary, $P=$ atmospheric pressure $(\mathrm{mmHg}), T=$ temperature of culture $\left({ }^{\circ} \mathrm{C}\right), f=$ gas flow-rate $(\mathrm{ml} . / \mathrm{min}$.), $x=$ concentration (dry weight) of bacteria in a culture (g./1.), $V=$ volume of culture.

Calculation of yield coefficients. The steady-state yield coefficient from glucose was calculated from

$$
Y_{\text {glucose }}=\frac{x}{s_{i}-s_{0}}
$$

where $x=$ concentration of organisms (g./l.), $s_{i}=$ glucose concentration in the feed medium (g./l.), $s_{0}=$ steady-state glucose concentration in the culture (g./1.).

Usually, $s_{0}$ was negligible compared with $s_{i}$, so that $Y_{\text {glucose }}=x / s_{i}$. The steady-state yield coefficient from oxygen $\left(Y_{\mathrm{O}_{2}}\right)$ was calculated from

$$
Y_{\mathrm{o}_{2}}=\frac{\mu}{Q_{\mathrm{o}_{2}}}
$$

where $\mu=$ specific growth rate $\left(\mathrm{h} .^{-1}\right)=$ dilution rate $Q_{\mathrm{o}_{2}}=$ specific respiration rate in situ (mmole/g. h.). 
RESULTS

Effect of growth conditions on growth yield

Temperature affects the maximum growth rate (Ingraham, 1962) and growth yield (Senez, 1962) of bacteria. Table I shows the growth yields obtained for a glucose-limited culture of Escherichia coli at different temperatures. The growth yield constant was unaffected by the temperature, between $15^{\circ}$ and $36^{\circ}$, although the maximum growth rate was much lower at $15^{\circ}$ than at $30^{\circ}$ or $36^{\circ}$. To obtain a steady state at $15^{\circ}$ the dilution rate had to be lowered to $0.05 \mathrm{~h}^{-1}$.

Table I. The effect of temperature on growth yield of a glucose-limited chemostat culture of Escherichia coli

\begin{tabular}{ccc}
\multicolumn{3}{c}{ Cultural conditions: $\mathrm{pH}=6.5$} \\
$\begin{array}{c}\text { Temperature } \\
\left({ }^{\circ} \mathrm{C}\right)\end{array}$ & $\begin{array}{c}\text { Growth rate } \\
\left(\mathrm{h} .{ }^{-1}\right)\end{array}$ & $\begin{array}{c}\text { Yield constant } \\
\text { (g. cells/g. glucose) }\end{array}$ \\
I5 & $0.05^{*}$ & $0.37 \pm 0.01$ \\
30 & 0.15 & $0.38 \pm 0.02$ \\
36 & 0.15 & $0.37 \pm 0.02$ \\
42 & No growth &
\end{tabular}

* This was the maximum growth rate that could be achieved under these conditions.

Table 2. The effect of $p H$ on the growth yield and $Q_{\mathrm{o}_{2}}$ of a glucose-limited chemostat culture of Escherichia coli

Cultural conditions: temperature $35^{\circ}$, growth rate $0.15 \mathrm{h.} .^{-1}$

$\begin{array}{ccc}\begin{array}{c}\mathrm{pH} \\ \text { value }\end{array} & \begin{array}{c}\text { Yield constant } \\ (\mathrm{g} . \text { cells/g. glucose })\end{array} & \begin{array}{c}Q_{\mathrm{o}_{2}}{ }^{*}(\text { in situ }) \\ \left(\mathrm{mmole} \mathrm{O}_{2} / \mathrm{g} . \mathrm{h} .\right)\end{array} \\ 8.2 & 0.35 \pm 0.02 \dagger & 5.5 \pm 0.3 \\ 7.5 & 0.39 \pm 0.02 \dagger & 5.5 \pm 0.3 \\ 7.0 & 0.37 \pm 0.02 \dagger & \text { n.d. } \\ 6.6 & 0.37 \pm 0.02 \dagger & 4.9 \pm 0.4 \\ 5.4 & 0.32 \pm 0.02 & 8.3 \pm 0.3 \\ \text { n.d. } & \text { Not determined. } \\ \text { Each value is the mean of duplicate estimations. } \\ + \text { Not significantly different at the } 95 \% \text { confidence level. }\end{array}$

The effect of $\mathrm{pH}$ on a glucose-limited culture is shown in Table 2. The organism grew at a rate of $0.15 \mathrm{~h}^{-1}$ between $\mathrm{pH} 5.4$ to 8.2 . There was no significant effect of $\mathrm{pH}$ on growth yield between $\mathrm{pH} 6.6$ to 8.2 . However, at pH 5.4 a lower yield of cells was obtained; the difference being significant at the $95 \%$ confidence level. (Significance was judged by the $t$-test applied to the technical error which was calculated from the results of more than 30 samples.) This lower yield was accompanied by a greater $Q_{\mathrm{o}_{2}}$ than that observed at higher $\mathrm{pH}$ values. At $\mathrm{pH} 5.4$ more substrate was expended in energy production and less was converted into cell material. Although a lower $Q_{\mathrm{o}_{2}}$ value was obtained at $\mathrm{pH} 6 \cdot 6$ than at $7 \cdot 5$ this difference was within the limit of technical error.

Effect of oxygen supply on growth yield and $Q_{\mathrm{O}_{2}}$

Harrison \& Pirt (1967) showed that the 'in situ' $Q_{0_{2}}$ of a culture of Klebsiella aerogenes was highest when the oxygen supply limited growth. In Escherichia coli as well as in 
$K$. aerogenes the 'in situ' $Q_{\mathrm{O}_{2}}$ was higher under limited oxygen conditions than in the presence of excess oxygen (Tables 3 and 4 ). The 'potential' $Q_{\mathrm{O}_{2}}$ was higher than the 'in situ' $Q_{\mathrm{O}_{2}}$ under all conditions of oxygen supply. With $E$. coli the maximum 'potential' $Q_{\mathrm{O}_{2}}$ was observed under limited oxygen conditions whereas with $K$. aerogenes the maximum value was attained after the organisms had been grown anaerobically for 3 days, when it was nearly double that found after growth with a limited supply of oxygen.

Table 3. The effect of oxygen supply on the respiration rate, yield constant and supernatant carbon of a glucose-limited chemostat culture of Escherichia coli

Culture conditions: $\mathrm{pH} 6.5$, temperature $35^{\circ}$, growth rate $0.15 \mathrm{~h} .^{-1}$

Growth conditions

Oxygen in excess

Limited oxygen

Anaerobic

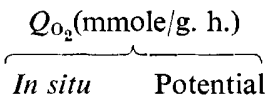

$\begin{array}{ll}5 \cdot 0 & 5.4 \\ 5 \cdot 0 & 6 \cdot 2\end{array}$

$5 \cdot 0$

$8 \cdot 8$

$-$

5.4
6.2
I6.0

I6.0

8.6$$
\begin{aligned}
& 9 \cdot 0 \\
& 8 \cdot 8
\end{aligned}
$$

$\begin{array}{cc}\begin{array}{c}\text { Yield } \\ \text { constant } \\ \text { (g. cells/g. glucose) }\end{array} & \begin{array}{c}\text { Supernatant } \\ \text { carbon } \\ \text { (mg./l.) }\end{array} \\ 0.36 \pm 0.02 & 131 \\ & 150 \\ 0.16 \pm 0.02 & 830 \\ 0.08 \pm 0.01 & 1300 \\ & 1400\end{array}$

Table 4. Effect of oxygen supply on the respiration rate, yield constant and supernatant carbon of a glucose-limited chemostat culture of Klebseilla aerogenes

Culture conditions: $\mathrm{pH} 6 \cdot 5$, temperature $30^{\circ}$, growth rate $0.2 \mathrm{I} \mathrm{h.} .^{-1}$

\begin{tabular}{|c|c|c|c|c|c|}
\hline \multirow[b]{2}{*}{ Growth conditions } & \multicolumn{2}{|c|}{$Q_{\mathrm{O}_{2}}(\mathrm{mmole} / \mathrm{g} . \mathrm{h})}$. & \multirow{2}{*}{$\begin{array}{c}\text { Yield } \\
\text { constant } \\
\text { (g. cells } / \text { g. glucose) }\end{array}$} & \multirow{2}{*}{$\begin{array}{l}\text { Supernatant } \\
\text { carbon } \\
\text { (mg./l.) }\end{array}$} & \multirow{2}{*}{$\begin{array}{l}\text { Supernatant } \\
\text { glucose } \\
\text { (mg./1.) }\end{array}$} \\
\hline & In situ & Potential & & & \\
\hline $\begin{array}{l}\text { Oxygen in excess } \\
\left(\mathrm{O}_{2} \text { tension } 5^{-1} 50 \mathrm{mmHg}\right)\end{array}$ & $5 \cdot 6 \pm 0 \cdot 3$ & $9 \cdot I \pm 0.3$ & $0.43 \pm 0.02$ & $255 \pm 50$ & $<50$ \\
\hline \multicolumn{6}{|l|}{$\begin{array}{l}\text { Limited } \mathrm{O}_{2} \\
\qquad\left(\mathrm{O}_{2} \text { tension }<5 \mathrm{mmHg}\right)\end{array}$} \\
\hline $\begin{array}{l}\text { Oxygen supply }<\text { demand } \\
\text { Oxygen supply } \leqslant \text { demand }\end{array}$ & $\begin{array}{l}9 \cdot 7 \pm 0.3 \\
7 \cdot 2 \pm 0.6\end{array}$ & $\begin{array}{l}10.9 \pm 0.4 \\
12 \cdot 7 \pm 0.8\end{array}$ & $\begin{array}{l}0.26 \pm 0.06 \\
0.14 \pm 0.2\end{array}$ & $\begin{array}{l}233 \pm 90 \\
900 \pm 170\end{array}$ & $\begin{array}{l}<50 \\
<50\end{array}$ \\
\hline \multicolumn{6}{|l|}{ Anaerobic } \\
\hline $\begin{array}{l}\text { For I day } \\
\text { For } 3 \text { days }\end{array}$ & - & $\begin{array}{l}10.6 \pm 0.7 \\
22.4+0.3\end{array}$ & $\begin{array}{l}0.13 \pm 0.03 \\
0.08+0.01\end{array}$ & $\begin{array}{r}860 \pm 170 \\
1020+90\end{array}$ & $\begin{array}{l}<50 \\
<50\end{array}$ \\
\hline
\end{tabular}

The yield constants were highest under fully aerobic conditions, lower with limited oxygen and least under anaerobic conditions. The supernatant carbon increased as the oxygen supply was diminished, because products were formed by glucose fermentation. When a culture of Klebsiella aerogenes was only just oxygen-limited (Table 4) the dissolved carbon concentration was about the same as the fully aerobic value, although the cell yield was decreased by nearly $40 \%$. This is the phase of 'uncoupled growth' which may give rise to stable oscillations (Degn \& Harrison, 1969) and, in fact, oscillations were observed at one stage of this experiment. 
Effect of growth rate on cell yield and $Q_{\mathrm{O}_{2}}$ of Klebsiella aerogenes

Fig. I $a$ shows the effect of changing growth rate on the 'in situ' and 'potential' $Q_{\mathrm{O}_{2}}$. At growth rates from 0.05 to $0.6 \mathrm{~h}^{-1}$ the 'in situ' $Q_{\mathrm{O}_{2}}$ rose linearly. This would be expected if growth were energy-limited according to the relation

$$
Q_{\mathrm{O}_{2}}=\frac{\mu}{Y^{\mathrm{ATP} N}}+\frac{M}{N}
$$

where $Q_{\mathrm{O}_{2}}=$ specific respiration rate (mole/g. h.), $\mu=$ specific growth rate $\left(\mathrm{h}^{-1}\right)=$ dilution rate, $Y^{\mathrm{ATP}}=$ cell yield coefficient for ATP $(\mathrm{g} . / \mathrm{mole})$ as proposed by Bauchop \& Elsden (1960), $N=$ number of moles ATP produced/mole oxygen taken up, $M=$ maintenance ATP requirement (moles/g. h.).

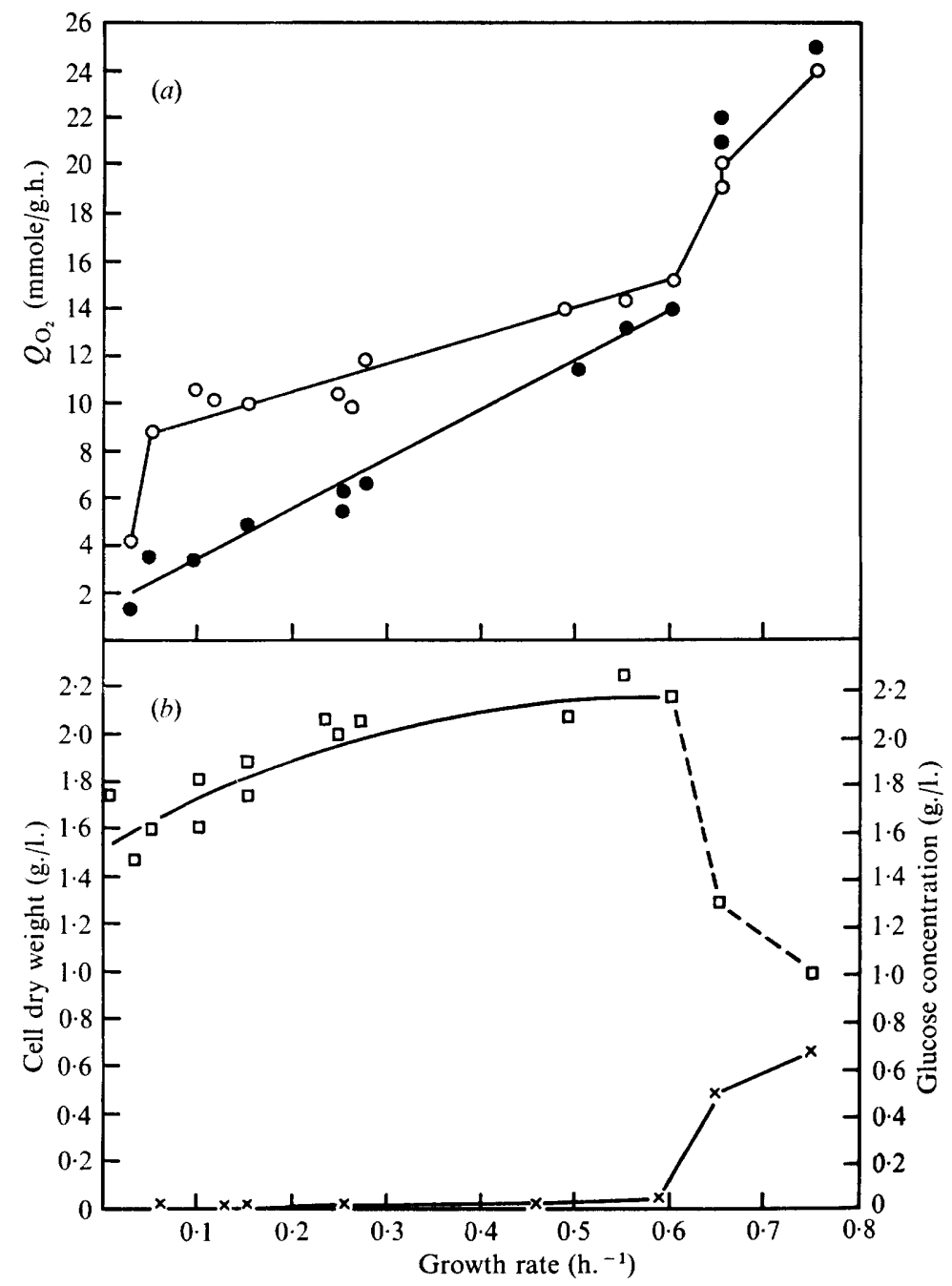

Fig. I. The effect of growth rate on cell dry wt concentration and $Q_{\mathrm{O}_{2}}$. $O$, potential $Q_{\mathrm{O}_{2}}$; in situ $Q_{\mathrm{O}_{2}} ; \square$, cell dry wt; $\times$, glucose concentration. Culture conditions: $\mathrm{pH} 6.5$, temperature $30^{\circ}$. 
The point where the extrapolated line cuts the $Q_{\mathrm{o}_{2}}$ axis gives the maintenance respiration rate (I.4 mmole/g. h.) which is equal to $M / N$. Assuming three sites of oxidative phosphorylation and two substrate-level phosphorylations/glucose molecule, $N=6 \cdot 3$, whence $M=$ $8.8 \mathrm{mmole}$ ATP $/ \mathrm{g}$. h.

The 'potential' $Q_{\mathrm{O}_{2}}$ increased more slowly with growth rate than the 'in situ' $Q_{\mathrm{o}_{2}}$. At a growth rate of $\mathrm{o}^{\cdot} \mathrm{I} \mathrm{h}^{-1}$ the 'potential' $Q_{\mathrm{O}_{2}}$ was about three times greater than the 'in situ' $Q_{0_{2}}$, but at a growth rate of $0.06 \mathrm{~h}^{-1}$ there was little difference between the 'potential' and 'in situ' $Q_{\mathrm{o}_{2}}$. At a very low growth rate $\left(0.025 \mathrm{~h}^{-1}\right)$ there was a sharp fall in 'potential' $Q_{\mathrm{O}_{2}}$. This might be due to the high proportion of non-viable cells present under these conditions (Postgate \& Hunter, I962).

Table 5. A comparison of growth parameters between the logarithmic phase of batch cultures and high-rate continuous culture of Klebsiella aerogenes

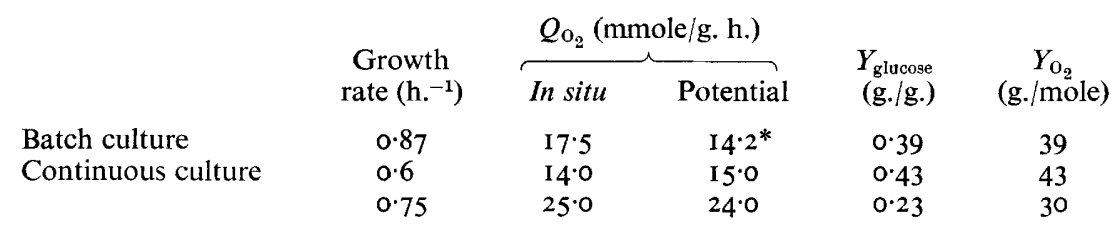

* Value obtained for washed, resuspended cells.

When the dilution rate was increased to $0.65 \mathrm{~h}^{-1}$ the cell concentration began to fall, but complete washout of culture did not occur; instead, the cell dry weight concentration settled at a new low level and a steady state was maintained for over 5 days. This steady state was accompanied by a high glucose concentration and both the 'potential' and ' in situ' $Q_{\mathrm{O}_{2}}$ values were much higher than at a dilution rate of $0.6 \mathrm{~h} .^{-1}$ (Fig. I $a$ ). Samples of a culture in this state were analysed for glucose by both the enzyme and anthrone methods. The results of the enzyme assay, which is specific for $\mathrm{D}-(+)$-glucose, is shown in Fig. I $b$. The anthrone method, which is non-specific and detects many types of reducing sugar including their polymers, gave values many times higher than the enzyme method. This discrepancy may have been caused by the production of extracellular polysaccharide in the culture.

The physiological state of the cells would appear to have been changed by increasing the growth rate from $0.60 \mathrm{~h} .^{-1}$ to $0.65 \mathrm{~h} .^{-1}$. In order to see whether the same physiological characteristics prevailed during the logarithmic phase of growth in batch culture, a batch culture of Klebsiella aerogenes was grown from a small inoculum in the continuous culture vessel under the same conditions of $\mathrm{pH}$, temperature and stirring as the continuous culture. In batch culture the cells grew at $0.87 \mathrm{~h}^{-1}$, but did not exhibit the high $Q_{\mathrm{o}_{2}}$ and low growth yield which had been observed with the continuous culture grown at a growth rate of $0 \cdot 75$ h. $^{-1}$ (Table 5).

According to conventional continuous culture theory (Herbert, Elsworth \& Telling, I956) the maximum attainable dilution rate in chemostat culture should be equal to the logarithmic growth rate of a batch culture under identical conditions. However, on increasing the dilution rate of the chemostat culture to $0.85 \mathrm{~h} .^{-1}$ the culture diluted out completely.

Herbert et al. (1956) also reported reduced cell concentrations at high growth rates in continuous culture and attributed this to imperfect mixing. However, in our experiments, the culture vessel was vigorously stirred at a rate of $900 \mathrm{rev} . / \mathrm{min}$. Possibly a medium constituent other than glucose became growth-limiting at high dilution rates. This could 
occur if the requirement for this substance increased with growth rate, as in the case of magnesium (Tempest, Hunter \& Sykes, 1965). However, the concentrations of all medium constituents apart from glucose were doubled without having any effect on cell concentration at a dilution rate of $0.75 \mathrm{~h} .^{-1}$. Addition of casamino acid and yeast extract $(0 . \mathrm{I} \%, \mathrm{w} / \mathrm{v})$ did not have any effect, neither did increasing the $\mathrm{CO}_{2}$ concentration in the gas phase up to $4 \%$. The nature of the limiting substance, if it exists, was not determined. Possibly the cells themselves produce a growth-regulating substance which can be maintained at an optimum level in batch culture or continuous culture at low dilution rates but which at high dilution rates washes out faster than it is formed.

\section{DISCUSSION}

The efficiency of growth of micro-organisms supplied with a single, limited source of both carbon and energy may be reduced if either the yield of utilizable energy from the substrate diminishes or if the energy requirement of the cells increases. In either case an inverse correlation would exist between respiration rate and cell yield. In this work little change was observed in the growth efficiency of Escherichia coli over a $20^{\circ}$ range of temperature which would indicate that the energy requirement for growth is little affected by temperature. However, the growth rate at $15^{\circ}$ was only $0.05 \mathrm{~h}^{-1}$ compared with $0.15 \mathrm{~h} .^{-1}$ at $30^{\circ}$ and $36^{\circ}$. From Fig. I it can be seen that the growth yield of Klebsiella aerogenes grown at $30^{\circ}$ is considerably lower at $0.05 \mathrm{~h}^{-1}$ than $0.15 \mathrm{~h}^{-1}$. This is accounted for by the comparatively greater proportion of energy that must be used for cell maintenance (equation (5)). If a similar relationship between cell yield and growth rate at $30^{\circ}$ applies to cultures of $E$. coli then it might be predicted that raising the temperature from $15^{\circ}$ to $30^{\circ}$ at a growth rate of $0.05 \mathrm{~h}^{-1}$ would cause a decrease in the growth yield. Such a result would indicate a dependence of energy of maintenance on temperature, the energy required for this purpose being decreased at low temperatures. The decreased efficiency of growth on lowering the $\mathrm{pH}$ of an $E$. coli culture to 5.4 may be caused by an increased energy requirement to pump ions in order to maintain a constant intracellular $\mathrm{pH}$.

The concept of growth yield coefficient from ATP ( $Y^{\text {ATP }}$ ) introduced by Bauchop \& Elsden (1960) is very useful for interpreting the energetics of cell growth. ATP is the 'coinage' for energy within a cell so that $Y^{\mathrm{ATP}}$ represents the efficiency of energy utilization by the cell.

Bauchop \& Elsden (1960) obtained a value of 10.5 for the $Y^{\text {ATP }}$ of several organisms grown anaerobically under glucose-limited conditions and suggested that this was the value for maximum efficiency. Lower values may be obtained under less favourable growth conditions and, from the data of Harrison \& Pirt (1967) for Klebsiella aerogenes grown under glucose-limited conditions in a simple synthetic medium, a value of $7 \cdot 1$ may be calculated.

Rearranging equation (5) gives an expression for $N$, the number of moles of ATP produced/molecule of oxygen taken up:

$$
N=\frac{\mu}{Y^{\mathrm{ATP}}} \frac{\mathrm{I}}{Q_{\mathrm{o}_{2}}-M / N} .
$$

$M / N$, the maintenance respiration rate, has been found to be $\mathrm{I} \cdot 4 \times 1 \mathrm{O}^{-3} \mathrm{~mole} / \mathrm{g} . \mathrm{h}$. If the maximum value of $Y^{\mathrm{ATP}}$ of 10.5 is inserted, a value can be obtained for the minimum ATP production/mole of oxygen. For three sites of oxidative phosphorylation and two substrate level phosphorylations, 38 ATP molecules will be produced per mole of glucose and per 
6 moles of oxygen, and $N$ will be $6 \cdot 3$. Similarly, for two or one sites of oxidative phosphorylation $N$ will be $4 \cdot 3$ or $2 \cdot 3$ respectively.

Applying equation (6) to the data of Fig. I, at a growth rate of $0.6 \mathrm{~h}^{-1}, N=4.8$ and at $0 \cdot \mathrm{I} \mathrm{h}^{-1} N=4 \cdot 3$, whereas at growth rates of 0.65 or $0.75 \mathrm{~h}^{-1} N=3.3$ or $3 \cdot$ I respectively. The low values at high growth rates represent a partial uncoupling of oxidative phosphorylation. From the data of Table 3 the value of $N$ obtained for a fully aerobic culture of Escherichia coli (assuming that the maintenance respiration is similar to that of Klebsiella aerogenes) is $4^{\circ} 0$ and for oxygen-limited growth is $\mathrm{I}^{\cdot} 9$. The values for $K$. aerogenes calculated from Table 4 are $N=4.7$ for fully aerobic conditions and $N=2.4$ for cells which were just oxygen-limited.

This may be interpreted as indicating that there are two sites of oxidative phosphorylation under fully aerobic conditions and that the ATP produced is used efficiently for growth. However, if the $Y^{\text {ATP }}$ value for these conditions were less than $10.5, N$ would be higher, indicating three sites of oxidative phosphorylation, with a high efficiency of energy utilization. The low values of $N$ for limited-oxygen conditions may arise from loss of coupling at a site of oxidative phosphorylation, so that efficiency of ATP production falls, or it may arise from a lower growth efficiency and decreased $Y^{\mathrm{ATP}}$. The former explanation would seem to be the more likely in the light of biochemical studies (Harrison \& Maitra, I969).

Reports that the efficiency of energy metabolism in aerobic cultures is extremely low (Wimpenny, 1969) seem to be based on erroneous calculations which fail to take into account the portion of the substrate converted into cell material. The conclusion from the results reported here is in broad agreement with the views of Chen (I964) and Hadjipetrou, Gerrits, Teulings \& Stouthamer (1964) that micro-organisms growing under carbonlimited aerobic conditions may utilize the ATP produced with an efficiency equal to anaerobically grown cells. However, it is clear that under some growth conditions the efficiency can fall to a low value and 'uncoupled' growth occurs (Gunsalus \& Shuster, I96I ; Senez, 1962).

In processes where cell production is the main aim any degree of 'uncoupling' of growth from energy metabolism clearly is to be avoided, but in waste-treatment systems such uncoupling is desirable as it leads to higher oxidation rates and lower yields of solids. Such studies as those presented here should help to define optimum conditions for oxidation of wastes. For instance, it seems that oxygen-limited conditions and/or high growth rates offer advantages which may be worth further investigation.

Other workers (Hino \& Maedo, I966; Cavari, Avi-dor \& Grossowicz, I968) observed extremely low respiration rates for Escherichia coli grown under strictly anaerobic conditions. This discrepancy may arise because although the 'anaerobic' cultures in our experiments contained very little oxygen, no steps were taken to remove the last traces of oxygen. Although the amount of residual oxygen was certainly insignificant as an electron acceptor, there may have been sufficient to àct as an inducer of respiratory enzymes. The higher 'potential' respiration rate is one aspect of the diminished cellular efficiency which is a consequence of the loss of the tight control over metabolism which functions in cells in the aerobic steady state of growth (Harrison \& Maitra, 1969). There is no correlation between cytochrome content of cells and the 'potential' respiration rate (Harrison et al. 1969). 


\section{REFERENCES}

BaUCHOP, J. \& ElsDEN, S. R. (1960). The growth of micro-organisms in relation to their energy supply. Journal of General Microbiology 23, 457-467.

Briggs, R., Melbourne, K. V. \& Eden, G. E. (1966). The monitoring to water quality. In Symposium on River Management, p. 38. Department of Civil Engineering, University of Newcastle-Upon-Tyne.

CAVARI, B. Z., AVI-Dor, Y. \& Grossowicz, N. (I968). Induction by oxygen of respiration and phosphorylation of anaerobically grown Escherichia coli. Journal of Bacteriology 96, 75I-759.

CHEN, S. L. (I964). Energy requirement for microbial growth. Nature, London 202, II $35-1136$.

DEGN, H. \& HARRISON, D. E. F. (I969). Theory of oscillation of respiration rate in continuous culture of Klebsiella aerogenes. Journal of Theoretical Biology 22, 238-248.

Elsworth, R., Meakin, R. P., Pirt, S. J. \& Capell, G. H. (1956). A two-litre scale continuous culture apparatus for micro-organisms. Journal of Applied Bacteriology 19, 264-278.

Gunsalus, I. C. \& Shuster, C.W. (196I). Energy-yielding metabolism in bacteria. In The Bacteria, Vol. II. Metabolism, pp. I-58. Edited by I. C. Gunsalus \& R. Y. Stanier. New York: Academic Press.

Hadipetrou, L. P., Gerrits, J. P., Teulings, F. A. G. \& Stouthamer, A. H. (1964). Relation between energy production and growth of Aerobacter aerogenes. Journal of General Microbiology 36, 139-150.

Harrison, D. E. F., Maclennan, D. M. \& Pirt, S. J. (I969). Responses of bacteria to dissolved oxygen tension. In Fermentation Advances, pp. I 17-144. Edited by D. Perlman. New York: Academic Press.

Harrison, D. E. F. \& MaItra, P. K. (1969). Control of respiration and metabolism in growing Klebsiella aerogenes: The role of adenine nucleotides. Biochemical Journal Ir2, 647-656.

Harrison, D. E. F. \& Melbourne, K. V. (I970). An autoclavable version of the Mackereth oxygen probe. Biotechnology and Bioengineering 12, 633-634.

Harrison, D. E. F. \& PIRT, S. J. (1967). The influence of dissolved oxygen concentration on the respiration and glucose metabolism of Klebsiella aerogenes during growth. Journal of General Microbiology 46, 193-2II.

Herbert, D., Elsworth, R. \& Telling, R. C. (1956). The continuous culture of bacteria: theoretical and experimental study. Journal of General Microbiology I4, 60 I-622.

Hino, S. \& MAEDo, M. ( I966). Effect of oxygen on the development of respiratory activity in Escherichia coli. Journal of General and Applied Microbiology, Tokyo 12, 247-265.

Ingraham, J. L. (1962). Temperature relationship. In The Bacteria, vol. IV. The Physiology of Growth, pp. 265-296. Edited by I. C. Gunsalus \& R. Y. Stanier. New York: Academic Press.

MACKERETH, F. J. H. ( 1964). An improved galvanic cell for determination of oxygen concentration in fluids. Journal of Scientific Instruments 4I, 38-4I.

MAGEe, N. J. (1955). Determination of organic nitrogen in the presence of high nitrates. Sanitalk 4, 26-27.

Postgate, J. R. \& Hunter, J. R. (1962). The survival of starved bacteria. Journal of General Microbiology 29, $233-263$.

SENEZ, J. C. (1962). Some considerations on the energetics of bacterial growth. Bacteriological Reviews 26, 95-107.

SLEIN, M. W. (1965). Determination with hexokinase and glucose-6-phosphate dehydrogenase. In Methods of Enzymatic Analysis, p. 117. Edited by H. U. Bergmeyer. New York and London: Academic Press.

Tempest, D. W., Hunter, J. R. \& Sykes, J. (1965). Magnesium-limited growth of Aerobacter aerogenes in a chemostat. Journal of General Microbiology 39, 355-366.

Trevelyan, W. E. \& Harrison, J. S. (I952). Studies on yeast metabolism. I. Fractionation and microdetermination of cell carbohydrates. Biochemical Journal 5o, 298-303.

WiMPENNY, J. W. T. (1969). Oxygen and carbon dioxide as regulators of microbial growth and metabolism. Symposia of the Society for General Microbiology 19, 161-193. 